\title{
Four-rod Technique Stabilization after Pedicle Subtraction Osteotomy (PSO) for the Treatment of Thoracolumbar Hyperkyphosis Secondary to Pott Disease: A Two-Year Follow-Up Case Report
}

\section{Técnica das quatro hastes após osteotomia de subtração pedicular para o tratamento de hipercifose toracolombar secundária à doença de Pott: Relato de caso de dois anos de seguimento}

Alecio Cristino Evangelista Santos Barcelos ${ }^{1,3}$ Sterphany Ohana Soares Azevedo Pinto ${ }^{2}$

Thaise Ellen de Moura Agra Teixeira ${ }^{3}$ Rayana Ellen Fernandes Nicolau 4

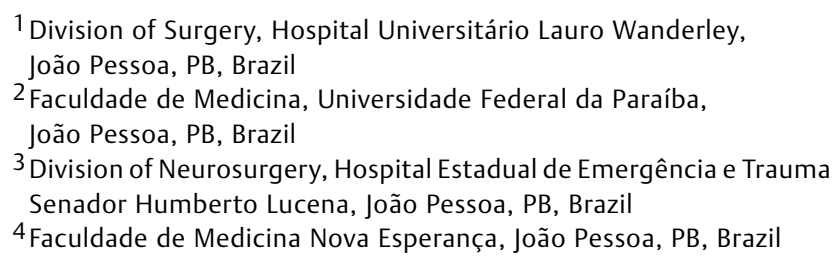

Address for correspondence Alecio Cristino Evangelista Santos Barcelos, MD, MSc, PhD, Divisão de Cirurgia, Hospital Universitário Lauro Wanderley, Avenida São Paulo 854, Bairro dos Estados, João Pessoa, 58030-040, Paraíba, Brazil (e-mail: aleciobarcelos.ineuro@gmail.com).

Arq Bras Neurocir 2019;38:219-226.

received April 3, 2019 accepted June 12, 2019
Pedicle subtraction osteotomy (PSO) is a powerful tool for the management of sagittal misalignment. However, this procedure has a high rate of implant failure, particularly rod breakages. The four-rod technique diminishes this complication in the lumbar spine. The aim of the present study is to provide a case report regarding PSO and fourrod technique stabilization in the treatment of short-angle hyperkyphosis in the thoracolumbar (TL) junction. The authors describe the case of a patient with TL hyperkyphosis secondary to spinal tuberculosis treated with L1 PSO and fixation with a four-rod technique. There were no major surgical complications. The self-reported quality of life questionnaires (the Short-Form Health Survey 36 [SF-36] and the Oswestry disability index) and radiological parameters were assessed preoperatively, as well as 6, 12 and 24 months after surgery, and they showed considerable and sustained improvements in pain control and quality of life. No hardware failure was observed at the two-year follow-up.

- thoracolumbar spine 


\section{Resumo}

$$
\begin{aligned}
& \text { Palavras-chave } \\
& \text { - osteotomia de } \\
& \text { subtração pedicular } \\
& \text { - cifose } \\
& \text { - tuberculose da } \\
& \text { coluna vertebral } \\
& \text { - técnica das quatro } \\
& \text { hastes } \\
& \text { - complicações pós- } \\
& \text { operatórias } \\
& \text { - coluna toracolombar }
\end{aligned}
$$

A osteotomia de subtração pedicular (OSP) é uma ferramenta importante no manejo de doenças com desalinhamento sagital. Entretanto, este procedimento apresenta altas taxas de falência do instrumental, em especial a quebra de hastes. A técnica de fixação com quatro hastes reduz essa complicação na região lombar. O objetivo deste estudo é relatar um caso de hipercifose na transição toracolombar (TL) tratado com OSP e estabilização com a técnica das quatro hastes. Os autores descrevem o caso de uma paciente com hipercifose TL secundária a tuberculose espinhal, tradada com PSO e fixação com a técnica das quatro hastes. Não houve complicações cirúrgicas maiores. Os questionários autorrelatados de qualidade de vida (Short-Form Health Survey 36 [SF-36] e índice de incapacidade de Oswestry) e os parâmetros radiográficos foram avaliados no pré-operatório e 6, 12 e 24 meses após a cirurgia, e demonstram considerável e estável melhora na qualidade de vida e no controle da dor da paciente. Não houve falência da instrumentação após 2 anos de seguimento.

\section{Introduction}

Pedicle subtraction osteotomy (PSO) is a powerful tool for the management of sagittal misalignment, and it can restore angular sagittal alignment up to $30^{\circ}$ to $40^{\circ}$. $^{1}$ However, rod breakage after PSO is common, occurring in 15.8 to $25 \%$ of patients who undergo this procedure. ${ }^{2-7}$ Most of these instrumental failures (89\%) occur at the index level vertebra or in adjacent vertebras. Furthermore, $71 \%$ of rod breakages happen in the first 12 months after the corrective surgery. ${ }^{5}$ Gupta et al (2017) ${ }^{3}$ reported the use of a 4-rod technique in lumbar PSO for the treatment of adult spinal deformities that had considerably reduced the rate of rod breakage.

The aim of the present study is to present the case of a patient with late thoracolumbar (TL) junction hyperkyphosis secondary to spinal tuberculosis that was successfully managed with PSO followed by four-rod technique stabilization.

\section{Case Report}

A 64-year-old woman was referred with severe mechanical low back pain that progressively increased mainly over the previous 6 months, and that was associated to pain in the buttocks and posterior thighs, without radicular trajectory. She was unable to stand or walk for more than 20 minutes. Ten years before she had been treated for spinal tuberculosis (also known as Pott disease) in the TL junction according to the Brazilian guidelines, with successful remission. ${ }^{8}$

\section{Neurological Examination}

The patient presented a forward trunk shift while standing or walking, and a TL junction kyphosis on inspection. On palpation, there was severe and painful paravertebral muscle contracture in the thoracic and lumbar regions. She reported severe back pain during assisted lumbar extension or rotation that was more intense in the lumbar region rather than in the apex of the deformity. The neurological examination was normal, except for bilateral hypoactive Achilles tendon reflexes. The Oswestry disability index (ODI) was of $32 \%$, a finding compatible with moderate disability. The Short-Form
Health Survey 36 (SF-36) physical and mental scores were 0 and 40 respectively.

\section{Diagnostic Imaging}

The computed tomography (CT) of the lumbar spine revealed TL kyphosis, with a wedge-shaped L1 vertebral body and sclerotic bone from T10 to L3 (-Fig. 1b). Narrowing of the spinal canal was observed at L1 and L2 by CT and magnetic resonance imaging (MRI), which also showed conus medullaris and cauda equina encroachment (-Fig. 1b-e). Scoliosis radiographs displayed a short-angle kyphosis with apex at L1 (T12L2 Cobb angle $\left.=34^{\circ}\right)$, thoracic hypokyphosis (T4T12 Cobb angle $=22^{\circ}$ ) and lumbar hyperlordosis (L1S1 Cobb angle $=69^{\circ}$ ). The spinopelvic parameter values were: pelvic incidence, $48^{\circ}$; pelvic tilt (PT), $13^{\circ}$; sacral slope, $35^{\circ}$; and sagittal vertical axis (SVA), $+1 \mathrm{~cm}$ ( - Table 1; - Fig. 2a and c). Surgical treatment was indicated due to refractory mechanical back pain secondary to TL hyperkyphosis and associated with lumbar hyperlordosis. Informed consent for the procedure was obtained from the patient.

\section{Surgical Technique}

The patient underwent an L1 PSO and spinal stabilization with the four-rod technique.

Positioning. After induction of general anesthesia, the patient was placed in prone position. Intraoperative neurophysiological monitoring (IONM) was not used.

Exposure. Through a midline incision, the paraspinal muscles were dissected subperiosteally from the spinous processes to the tip of the transverse processes from T9 to L4.

Instrumentation. The pedicle screws were inserted four levels above and three levels below the wedge vertebra (L1) under the guidance of fluoroscopy. In T9, T10, T11, L3 and L4, the entry points were in the superior facets. In T12 and L2, the entry points were in the mammillary processes, and their trajectories were of $22^{\circ}$ to $30^{\circ}$ medial to the sagittal plane, rather than the usual $0^{\circ}$ to $10^{\circ}$ at these levels. Thus, the screw heads of the levels adjacent to L1 were more lateral and slightly deeper than the cranial and caudal ones ( - Fig. $3 d$ ). 


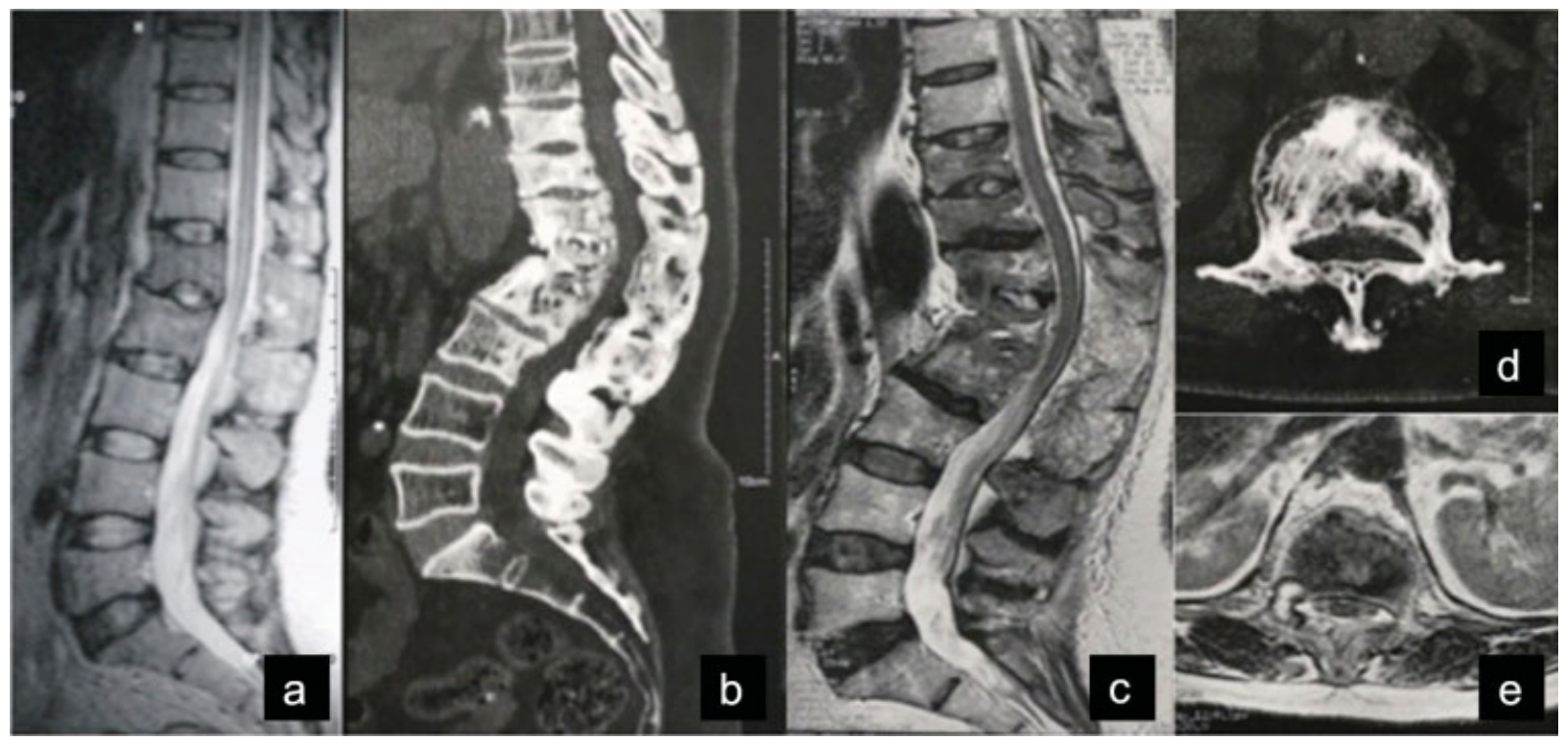

Fig. 1 A 64-year-old female was diagnosed with Pott disease and treated conservatively. The lumbar spine magnetic resonance imaging (MRI) exam - T2 sequence - shows a hypointense signal at L1 and L2 (a). Ten years later, the computed tomography (CT) and the MRI (b, c, d and e) show thoracolumbar (TL) junction kyphosis, bone sclerosis from T10 to L3, and spinal canal narrowing.

Table 1 Preoperative, Postoperative and Follow-Up Values of the Sagittal Balance Parameters

\begin{tabular}{|l|l|l|l|l|}
\hline Sagittal balance parameter & Preop & 6 months po & 12 months po & 24 months po \\
\hline T4-T12 thoracic kyphosis $\left(^{\circ}\right)$ & $+22^{\circ}$ & $+41^{\circ}$ & $+43^{\circ}$ & $+40^{\circ}$ \\
\hline T12-L2 angle $\left(^{\circ}\right)$ & $+34^{\circ}$ & $+3^{\circ}$ & $+6^{\circ}$ & $11^{\circ}$ \\
\hline L2-S1 lumbar lordosis $\left(^{\circ}\right)$ & $-69^{\circ}$ & $-57^{\circ}$ & $-55^{\circ}$ & $-58^{\circ}$ \\
\hline Sagittal vertical axis $(\mathrm{cm})$ & +1 & +1 & +1 & +1 \\
\hline Pelvic tilt $\left(^{\circ}\right)$ & $13^{\circ}$ & - & $10^{\circ}$ & $8^{\circ}$ \\
\hline
\end{tabular}

Abbreviations: po, postoperative; preop, preoperative.

Pedicle subtraction osteotomy. The osteotomy was performed at $\mathrm{L} 1$ as previously described. ${ }^{9,10}$ The posterior elements of $\mathrm{L} 1$, including the pedicles and transverse processes, were removed, as well as the spinous process and the caudal half of the T12 lamina. The nerve roots of T12 and L1 were exposed bilaterally. Finally, a partial wedge resection of the posterior vertebral body of L1 was performed mainly with osteotomes, and completed with rongeurs and a drill. In this step, the fluoroscopy was paramount to delineate the directions of the osteotomes, as well as the angle of the bone fragment to be removed (- Fig. 3a and $\mathbf{b}$; - Fig. 4a). Incidental durotomy occurred, but it was promptly sutured. The disks above and below remained intact. Before the closing procedure, a temporary rod was used to avoid translation in one side when the other side of the osteotomy was done. ${ }^{11}$

Kyphosis correction. Closure of the osteotomy was performed by bilateral alternating compression maneuvers over the screw heads of T12 and L2, fixed with short rods (-Fig. 3c; - Fig. 4b and c). During the PSO, hemostasis with bone wax was avoided on the bone defect surfaces to prevent pseudarthrosis. Subtle compression of the left L1 nerve root was noticed soon after the osteotomy closure, and decompression was readily performed.

Stabilization, grafting and closure. Final stabilization was obtained with long titanium rods $(6.0 \mathrm{~mm})$ and caps inserted and tightened from T9 to L4, with satisfactory correction of the TL junction kyphosis. After decortication, local bone grafts were placed posterolaterally. To stiffen the construct, cross-links were used to connect the long rods to one another and to connect the short rods to the long ones ipsilaterally. Intraoperative fluoroscopy showed adequate placement of implants and correction of TL kyphosis (-Fig. 3c, d and e; - Fig. 4c and d). Intrawound vancomycin powder $(2 \mathrm{~g})$ was used. ${ }^{12-14}$ The wound was closed in layers, and a closed suction drain was left in place for 48 hours. The operating time was 515 minutes, and the patient received a packed red blood cell transfusion $(950 \mathrm{~mL})$.

\section{Follow-up}

The length of stay of the patient in the hospital was of 5 days. The patient presented bilateral meralgia paresthetica despite the protection of the iliac crests with cotton paddles. A TL vest was not recommended. Sixteen days postoperatively, she complained of moderate back pain and severe meralgia paresthetica, without motor function compromise. An examination revealed a superficial wound infection with no fluid leakage, which was solved with oral antibiotics for 3 weeks. The pain was treated with pregabalin (150 mg per day) for 6 months, and codeine (30 mg every 4 hours as needed). 


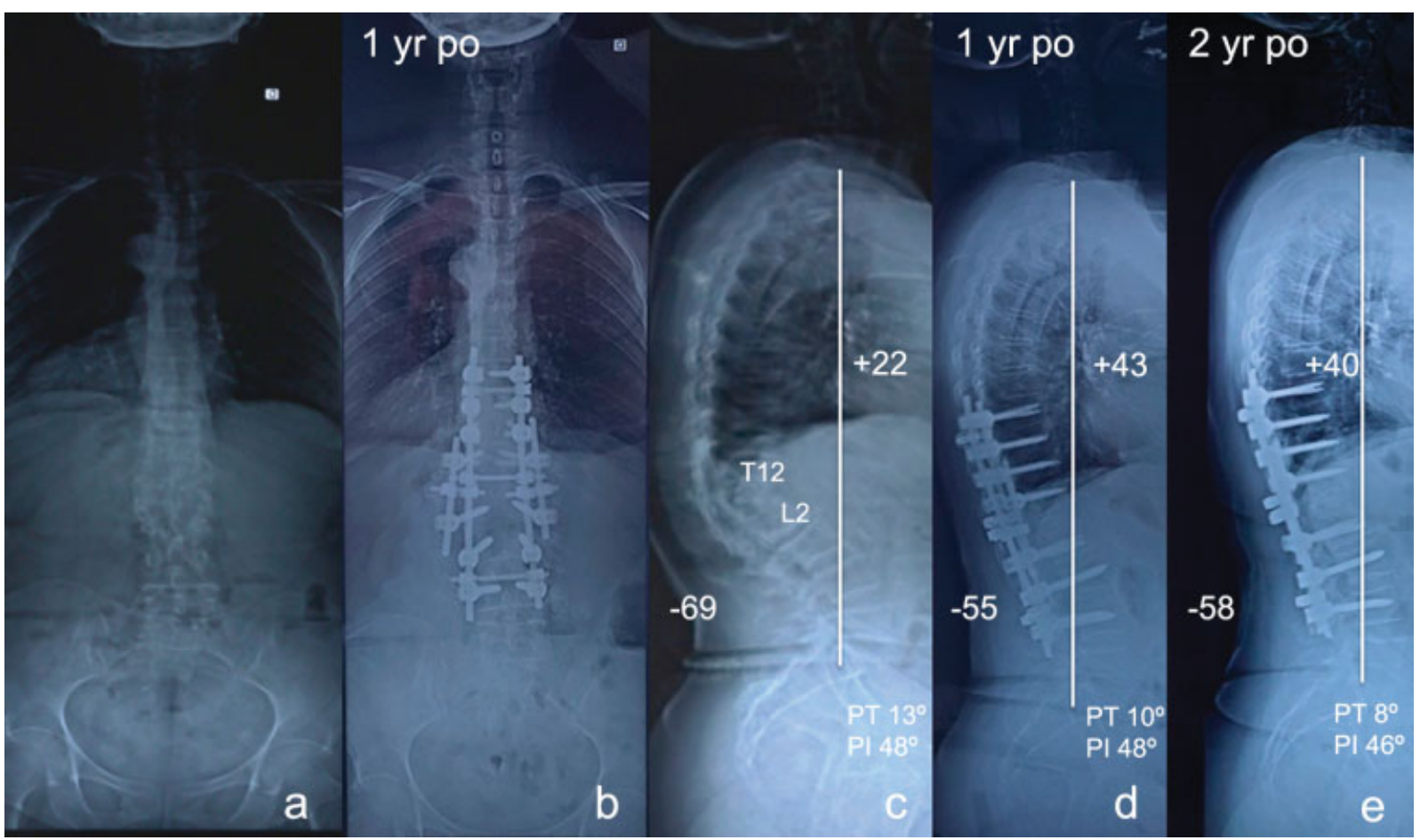

Fig. 2 Preoperative standing radiographs (a and c) show short angular kyphosis with apex at L1 (Cobb angle: $34^{\circ}$ ) and normal sagittal vertical axis (SVA). After pedicle subtraction osteotomy (PSO) at L1 using 4-rod fixation, the thoracolumbar (TL) transition angle was restored (Cobb angle: $11^{\circ}$ at the 2-year follow-up), and the compensatory thoracic hypokyphosis and lumbar hyperlordosis were solved.

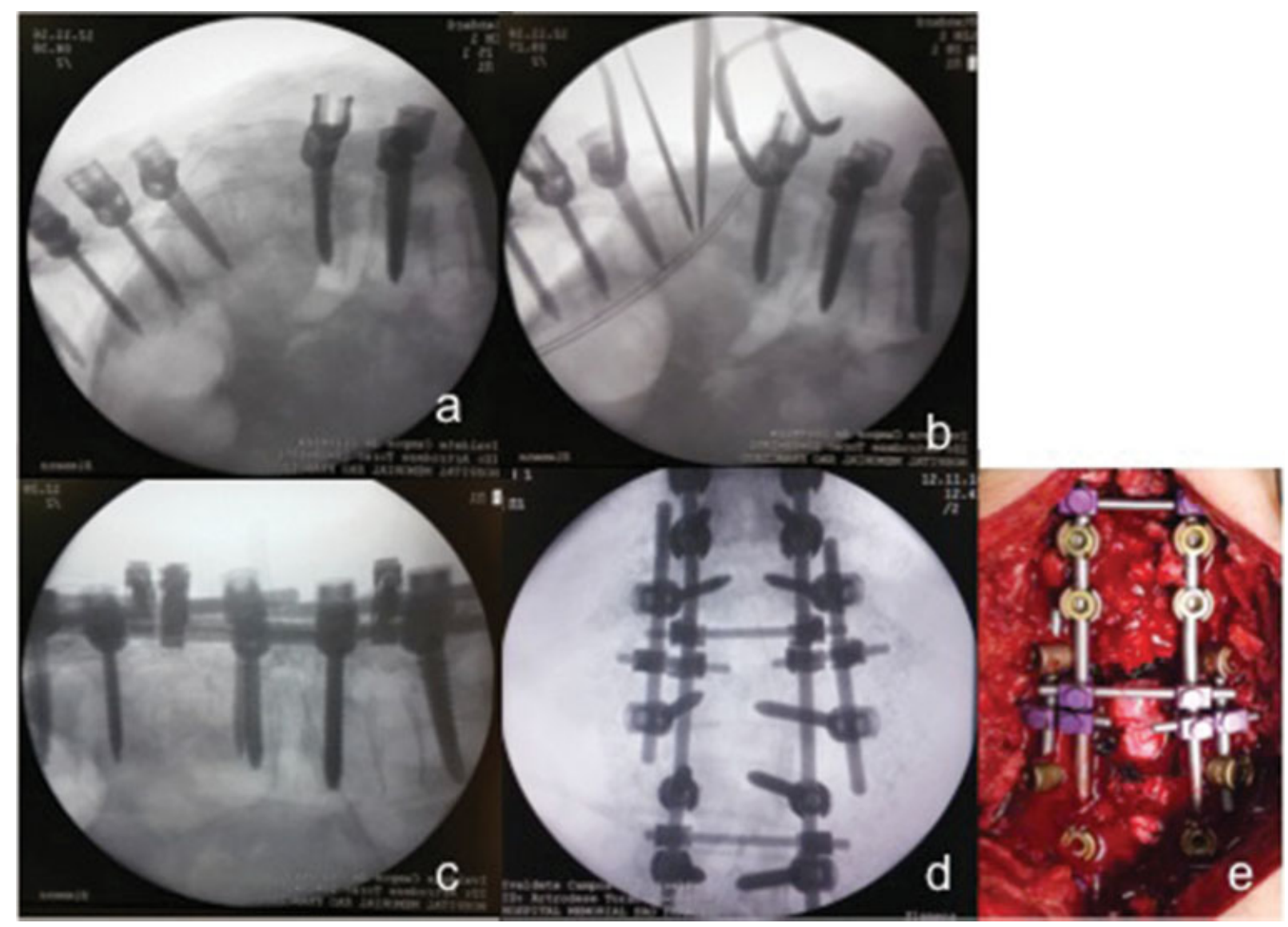

Fig. 3 Pedicle screws were inserted 4 levels above and 3 levels below the wedge vertebra (L1). InT12 and L2, the entry points were lateral at the junction of the superior facet and transverse processes (a). Pedicle subtraction osteotomy (PSO) was performed at the apex (L1) of the kyphosis and closed with bilaterally alternating compression maneuvers over the screw heads of T12 and L2, fixed with short rods. Final stabilization was obtained with long rods (c, d and e). 
a

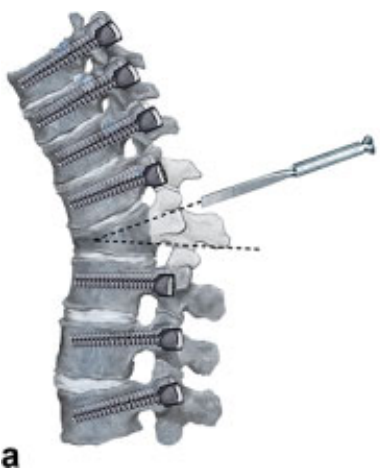

b

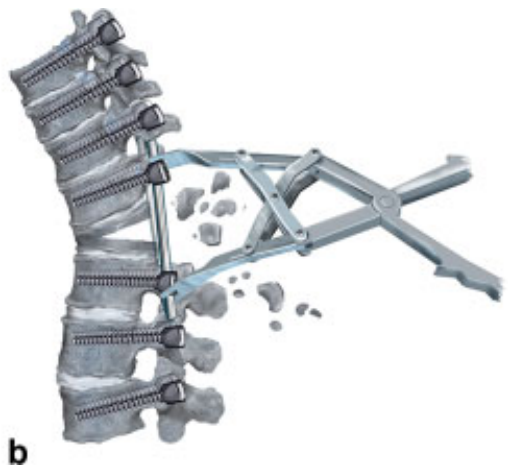

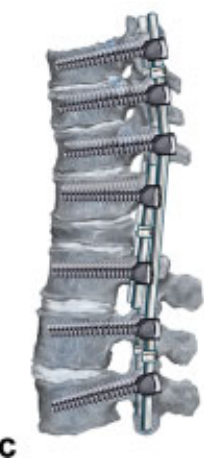

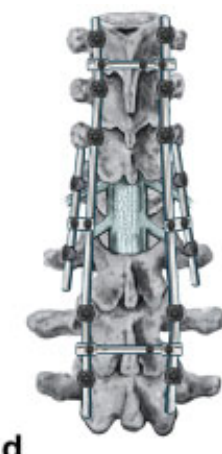

d

Fig. 4 Schematic illustrations of pedicle subtraction osteotomy (PSO) and four-rod technique stabilization to treat thoracolumbar hyperkyphosis. First, the pedicle screws are placed, then the posterior arches of T12 and L1, as well as the L1 pedicles, are removed; finally, the PSO is performed (a). Compression maneuver over the T12 and L2 screws heads to close the bone defect and correct the hyperkyphosis, followed by short rods locking, and then long-rod fixations ( $b$ and $c$ ). Posterior 3D image showing the final aspect of the instrumentation (d).

\section{Radiological Outcomes}

Standing scoliosis radiograph images 6,12 and 24 months after the procedure showed normal sagittal alignment parameters, without compensatory mechanisms and no signs of pseudarthrosis or implant failure ( $\mathbf{- T a b l e} \mathbf{1}$ and $\boldsymbol{- F i g . 2}$ ). Considerable improvements were observed in the thoracic kyphosis $\left(+22^{\circ}\right.$ versus $\left.+40^{\circ}\right)$ and lumbar lordosis $\left(-69^{\circ}\right.$ versus $\left.-58^{\circ}\right)$ when the images obtained 24 months after the surgery were compared with the preoperative images (-Table 1, - Fig. 2 ).

\section{Clinical Outcomes}

Six months postoperatively, the patient reported considerable improvement in both back pain and meralgia paresthetica, with sporadic use of analgesic drugs. Self-reported outcome questionnaires showed significant improvement at 6 months, which was maintained 12 and 24 months postoperatively. At the final follow-up, she reported considerable spine pain relief and increase in quality of life, despite feeling unilateral hip joint pain, which was managed conservatively ( - Table 2 ).

\section{Discussion}

Thoracolumbar hyperkyphosis may cause sagittal misalignment, which is characterized by a forward dislocation of the body's gravitational center that elicits compensatory mechanisms, mainly thoracic hypokyphosis and lumbar hyperlordosis

Table 2 Clinical Assessment by Self-Reported Outcome Questionnaires: Preoperative, 6 Months and 12 Months Postoperatively

\begin{tabular}{|l|l|l|l|l|}
\hline Parameter & \multicolumn{3}{|l|}{ Evaluation period } & \\
\hline & Preop & $\begin{array}{l}6 \text { months } \\
\text { po }\end{array}$ & $\begin{array}{l}12 \text { months } \\
\text { po }\end{array}$ & $\begin{array}{l}24 \text { months } \\
\text { po }\end{array}$ \\
\hline $\begin{array}{l}\text { SF-36 } \\
\text { (physical) }\end{array}$ & 0 & 100 & 100 & 75 \\
\hline $\begin{array}{l}\text { SF-36 } \\
\text { (mental) }\end{array}$ & 40 & 84 & 84 & 84 \\
\hline ODI & $32 \%$ & $0 \%$ & $18 \%$ & $6 \%$ \\
\hline
\end{tabular}

Abbreviations: ODI, Oswestry disability index; po, postoperative; preop, preoperative; SF-36, Short-Form Health Survey 36. due to paravertebral muscle contractures, resulting in increased energy expenditure and chronic back pain. ${ }^{15-19}$ Secondary trunk extension also overloads the facet joints, resulting in a painful condition as well. ${ }^{17,19,20}$ Thus, restoration of the sagittal alignment counteracts this process and relieves discomfort. $^{21}$

The reported case showed hyperkyphosis at the TLjunction, the most common site affected by spinal tuberculosis. ${ }^{22-24}$ According to the global alignment concept, the patient had hidden sagittal imbalance, as shown by the thoracic hypokyphosis $\left(+22^{\circ}\right)$, and lumbar hyperlordosis $\left(-69^{\circ}\right)$, which was associated with a preoperatively balanced pelvis (sagittal vertical axis (SVA): $1 \mathrm{~cm}$; PT: $\left.13^{\circ}\right) .{ }^{25}$

Surgery is best indicated when there is significant pain associated with a kyphotic segmental deformity exceeding $20^{\circ} .{ }^{26}$ Surgical treatment is also recommended if there is progressive neurological deficit secondary to canal encroachment and/or spinal cord tethering at the apex of the kyphosis, usually in the thoracic spine.

Different types of osteotomy might be necessary to treat hyperkyphosis. ${ }^{1,9}$ The decision about which osteotomy to use depends on the anatomy of the lesion, the amount of angular correction needed to restore global spine alignment, and the type of curve (long or short). Ponte osteotomies (Schwab 2) at multiple levels allow corrections of $5^{\circ}$ to $10^{\circ}$ per level, and are recommended mainly for long kyphotic curves. A PSO, with or without superior diskectomy (Schwab 4 and 3 respectively), enables corrections of $30^{\circ}$ to $45^{\circ}$, and is indicated to address short-angle hyperkyphosis. ${ }^{1,9,27-31}$ However, in cases of severe kyphosis, mainly higher than $60^{\circ}$, vertebral column resection might be needed..$^{32-37}$ Thus, through a single posterior approach, a three-column osteotomy (PSO or vertebral column resection [VCR]) may enable the correction of sagittal misalignment in pathologies such as posttraumatic kyphosis, postinfection kyphosis, congenital deformities, adult spinal deformities, ankylosing spondylitis, and iatrogenic flat back. ${ }^{17}$

Gupta et al (2017) ${ }^{3}$ have described a new 4-rod technique in which all rods are connected to pedicle screws in cases of lumbar PSO (L2, L3 and L4) for the treatment of adult spinal deformities. The two short rods are used to stabilize the 
superior and inferior vertebras that are adjacent to the osteotomy level. The two other rods connect the remaining levels involved in the instrumentation (holding rods). None of the 29 patients treated with the Gupta technique experienced rod breakage during a 5-year follow-up. In comparison, the 4-rod technique decreased the rate of implant failure after PSO from 25\% to 0 during a 5-year follow-up ( $p=0.008$; Gupta et al, 2017). ${ }^{3}$

In the TL junction, PSO has been successfully used to correct posttraumatic kyphosis as well as Pott-disease deformities. Significant improvement in clinical outcomes has been achieved after PSO for the treatment of TL hyperkyphosis secondary to tuberculosis, a result that has been related to hyperkyphosis correction and restoration of normal sagittal alignment. ${ }^{29,33}$ In the present case we used the 4-rod pediclebased technique to stabilize a short-angle TL kyphosis after L1 PSO.

Pseudarthrosis and implant failures (mainly rod breakage) are frequent complications after a PSO, since the correction of deformity places the implants under huge mechanical stress. $^{3,11,29,31,34,38-40}$ There are other strategies to improve the construct biomechanical stability and bone fusion to prevent rod breakage.

A large gap remains between the upper and lower transverse vertebral processes after PSO. Thus, autologous bone grafting should completely fill the posterolateral sites bilaterally. Furthermore, interbody implants with autografts in the cranial and caudal intervertebral disc spaces can be added to improve arthrodesis. ${ }^{41}$ However, they do not seem to reduce motion or strain; instead they act mainly to maintain disk height. ${ }^{42,43}$ They should preferably be placed prior to the osteotomy, before possible major bleedings. Although the use of cross-links might stiffen the construct, it can diminish the surface for bone fusion. One should set the bone graft before placing the cross-links to diminish this effect.

Placing additional accessory rods, connected to the holding rods with domino/cross-links, has proved to enhance the stability and stiffness of the construct in cases of 3-column osteotomy in both biomechanical and clinical studies (17\% versus $3 \%$ when compared with standard 2 -rod constructs). ${ }^{11,44}$

A biomechanical study ${ }^{45}$ has shown that regarding the range of motion, two or four rods, made either of titatinum (Ti) or cobalt chrome ( $\mathrm{CoCr}$ ), have significantly and similarly (94.9\% versus $99.4 \%$ ) reduced flexion-extension and lateral bending when compared with the intact cadaveric lumbar spine model. However, total rod strain, which represents the stress delivered to the rods during the biomechanical cycles, both in flexion and extension, significantly decreased with accessory rods when compared with the Ti 2 -rod (46\% versus $65 \%$ for the $\mathrm{Ti} 4$-rod and $\mathrm{CoCr}$ 4-rod respectively). Even though the $\mathrm{CoCr}$ rod significantly reduces rod strain, the use of accessory rods with either material provided the most immediate fixation. Besides, these rods receive greater strain than the primary rods. ${ }^{45}$

Deformity corrections with PSO are demanding procedures with high rates of complications (37\% and $67 \%$ when performed in the lumbar and thoracic regions respectively), including 12 to $30 \%$ of sensitive or motor neurological deficits, most of them transient. ${ }^{46-48}$ Intraoperative neurophysiological monitoring has presumably positive effects in identifying neurological deficits, but it still might neglect some neurological injuries. ${ }^{49}$ Therefore, although IONM should be used in deformity corrective surgery involving PSO whenever available, its role in the decrease of new neurological deficits is still unclear. $^{50}$ An experimental study in swine ${ }^{51}$ has demonstrated that spinal cord injury (SCI) occurred when the shortening was equivalent to the height of one vertebra at the thoracolumbar level. Thus, a PSO performed to correct sagittal TL hyperkyphosis should not result in neurological damage if judicious care is taken with dural sac retraction (more protection than retraction) and wide emerging root decompressions followed by inspection of neural elements during and after osteotomy closure.

The mean blood loss during a PSO is of $55 \%$ of the patient's volemia, and in $24 \%$ of cases there can be losses of $\sim 4 \mathrm{~L}$ of blood. ${ }^{48}$ Thus, a cell saver should be preferably used to avoid massive transfusion. Dural tear is the most common complication after PSO for the treatment of short-angle kyphosis $(15.8 \%) .{ }^{34}$

\section{Conclusions}

The present report highlights the rationale, surgical steps and outcome of spinal stabilization with the four-rod technique after a PSO in the TL junction. During a two-year follow-up, there was no pseudarthrosis or implant failure, and the patient experienced sustained improvement in pain control and quality of life, as depicted by the self-reported questionnaires. This technique has been proven to increase construct stiffness and prevent rod breakages in the lumbar spine. Also, the placement of short rods (and screws) is feasible, and should not considerably increase the complications and the operating time. Despite this, the technique must still be compared in larger series to other procedures used in the correction of short-angle kyphosis in the TL junction, such as circumferential stabilization, as well as PSO and two-rod fixation.

Ethical approval and consent to participate

The medical ethics committee of the Medical Sciences Center at Universidade Federal da Paraíba approved this study under the following registration number: CAAE 89898718.3.0000.8069. Before and during the present study, informed consent was obtained from the participant after a brief discussion and explanation.

\section{Consent for publication}

Written informed consent was obtained from the patient for the publication of this case report and its accompanying images.

\section{Availability of data and materials}

The data and materials used during the present study are available from the corresponding author on reasonable request. 


\section{Competing interests}

The authors report no competing interests concerning the materials or methods used in the present study or the findings specified in this paper.

\section{Author contribution}

$\mathrm{AB}$ was in charge of patient management. He also wrote the case summary, and was responsible for supervising, correcting and proof-reading the writings of other authors. SP was involved in writing the manuscript alongside $A B$, as well as in maintaining patient follow-up. TT was involved in patient management; she supervised and proof-read the writings of other authors as well. RN participated in the writings of the discussion session. All authors read and approved the final manuscript.

\section{Funding}

The authors received no financial support for the research, authorship, and/or publication of the present article.

\section{Conflict of Interests}

The authors have none to declare.

\section{Acknowledgments}

The authors are grateful to Fernando Mosca for his skillful illustrations.

\section{References}

1 Kim K-T, Park K-J, Lee J-H. Osteotomy of the spine to correct the spinal deformity. Asian Spine J 2009;3(02):113-123http://synapse.koreamed.org/DOIx.php?id=10.4184/asj.2009.3.2.113 [Internet]

2 Bridwell KH, Lewis SJ, Edwards C, et al. Complications and outcomes of pedicle subtraction osteotomies for fixed sagittal imbalance. Spine 2003;28(18):2093-2101http://content.wkhealth. com/linkback/openurl?sid=WKPTLP:landingpage $\& a n=0000763$ 2-200309150-00011 [Internet]

3 Gupta S, Eksi MS, Ames CP, et al. A Novel 4-Rod Technique Offers Potential to Reduce Rod Breakage and Pseudarthrosis in Pedicle Subtraction Osteotomies for Adult Spinal Deformity Correction. Oper Neurosurg (Hagerstown) 2017;0(00):1-8https://academic. oup.com/ons/article-lookup/doi/10.1093/ons/opx151 [Internet]

4 Gupta S, Eski MS, Durbin-Johnson B, Ames C, Deviren V, Gupta M. Four Rods Prevent Rod Breakage and Pseudoarthrosis in Pedicle Subtraction Osteotomies. In: Spine: Affiliated Society Meeting Abstracts [Internet]. 2014. p. 269-70. Available from: http:// journals.sagepub.com/doi/10.1177/155005940403500413

5 Smith JS, Shaffrey CI, Ames CP, et al; International Spine Study Group. Assessment of symptomatic rod fracture after posterior instrumented fusion for adult spinal deformity. Neurosurgery 2012;71(04):862-867

6 Smith JS, Shaffrey E, Klineberg E, et al; International Spine Study Group. Prospective multicenter assessment of risk factors for rod fracture following surgery for adult spinal deformity. J Neurosurg Spine 2014;21(06):994-1003http://thejns.org/doi/10.3171/2014.9. SPINE131176 [Internet]

7 Smith JS, Klineberg E, Lafage V, et al; International Spine Study Group. Prospective multicenter assessment of perioperative and minimum 2-year postoperative complication rates associated with adult spinal deformity surgery. J Neurosurg Spine 2016;25(01):1-14

8 Ministério da Saúde do Brasil. Manual de Recomendações para o Controle da Tuberculose no Brasil [Internet]. Brasília; 2011. 288 p.
Available from: http://bvsms.saude.gov.br/bvs/publicacoes/manual_recomendacoes_controle_tuberculose_brasil.pdf

9 Schwab F, Blondel B, Chay E, et al. The comprehensive anatomical spinal osteotomy classification. Neurosurgery 2014;74(01):112-120, discussion 120 http://www.ncbi.nlm.nih.gov/pubmed/24193360\%0 Ahttp://content.wkhealth.com/linkback/openurl?sid=WKPTLP: landingpage\&an $=00006123-900000000-98168$ [Internet]

10 Thomasen E. Vertebral osteotomy for correction of kyphosis in ankylosing spondylitis. Clin Ortop Relat Res 1985;(194):142-152

11 Hyun SJ, Lenke LG, Kim YC, Koester LA, Blanke KM. Comparison of standard 2-rod constructs to multiple-rod constructs for fixation across 3-column spinal osteotomies. Spine 2014;39(22):1899-1904

12 Strom RG, Pacione D, Kalhorn SP, Frempong-Boadu AK. Lumbar laminectomy and fusion with routine local application of vancomycin powder: decreased infection rate in instrumented and non-instrumented cases. Clin Neurol Neurosurg 2013;115(09): 1766-1769. Doi: 10.1016/j.clineuro.2013.04.005 [Internet]

13 Molinari RW, Khera OA, Molinari WJ III. Prophylactic intraoperative powdered vancomycin and postoperative deep spinal wound infection: 1,512 consecutive surgical cases over a 6-year period. Eur Spine J 2012;21(Suppl 4):S476-S482http://link. springer.com/10.1007/s00586-011-2104-z [Internet]

14 Sweet FA, Roh M, Sliva C. Intrawound application of vancomycin for prophylaxis in instrumented thoracolumbar fusions: efficacy, drug levels, and patient outcomes. Spine 2011;36(24):2084-2088

15 Kuntz C IV, Levin LS, Ondra SL, Shaffrey CI, Morgan CJ. Neutral upright sagittal spinal alignment from the occiput to the pelvis in asymptomatic adults: a review and resynthesis of the literature.J Neurosurg Spine 2007;6(02):104-112http://thejns.org/doi/10.3171/spi.2007.6.2.104 [Internet]

16 Panjabi MM. A hypothesis of chronic back pain: ligament subfailure injuries lead to muscle control dysfunction. Eur Spine J 2006;15(05):668-676

17 Van Royen BJ, Toussaint HM, Kingma I, et al. Accuracy of the sagittal vertical axis in a standing lateral radiograph as a measurement of balance in spinal deformities. Eur Spine J 1998;7(05): 408-412

18 Barrey C, Roussouly P, Le Huec JC, D’Acunzi G, Perrin G. Compensatory mechanisms contributing to keep the sagittal balance of the spine. Eur Spine J 2013;22(Suppl 6):S834-S841

19 Gelb DE, Lenke LG, Bridwell KH, Blanke K, McEnery KW. An analysis of sagittal spinal alignment in 100 asymptomatic middle and older aged volunteers. Spine 1995;20(12):1351-1358

20 Munting E. Surgical treatment of post-traumatic kyphosis in the thoracolumbar spine: indications and technical aspects. Eur Spine J 2010;19(Suppl 1):S69-S73

21 Savage JW, Patel AA. Fixed sagittal plane imbalance. Glob spine J 2014;4(Suppl 4):287-296. Available from: https://www.ncbi. nlm.nih.gov/pubmed/25396111

22 Bydon A, Dasenbrock HH, Pendleton C, McGirt MJ, Gokaslan ZL, Quinones-Hinojosa A. Harvey Cushing, the spine surgeon: the surgical treatment of Pott disease. Spine 2011;36(17):1420-1425

23 Issack PS, Boachie-Adjei O. Surgical correction of kyphotic deformity in spinal tuberculosis. Int Orthop 2012;36(02):353-357

24 Rajasekaran S. Kyphotic deformity in spinal tuberculosis and its management. Int Orthop 2012;36(02):359-365

25 Lamartina C, Berjano P. Classification of sagittal imbalance based on spinal alignment and compensatory mechanisms. Eur Spine J 2014;23(06):1177-1189

26 Farcy J-P, Weidenbaum M, Glassman SD. Sagittal index in management of thoracolumbar burst fractures. Spine 1990;15(09): 958-965

27 Terran J, Schwab F, Shaffrey CI, et al; International Spine Study Group. The SRS-Schwab adult spinal deformity classification: assessment and clinical correlations based on a prospective operative and nonoperative cohort. Neurosurgery 2013;73(04):559-568

28 Pérez-Grueso FS, Cecchinato R, Berjano P. Ponte osteotomies in thoracic deformities. Eur Spine J 2015;24(Suppl 1):S38-S41 
29 Rajasekaran S, Vijay K, Shetty AP. Single-stage closing-opening wedge osteotomy of spine to correct severe post-tubercular kyphotic deformities of the spine: a 3-year follow-up of 17 patients. Eur Spine J 2010;19(04):583-592

30 Li F, Sagi HC, Liu B, Yuan HA. Comparative evaluation of singlelevel closing-wedge vertebral osteotomies for the correction of fixed kyphotic deformity of the lumbar spine: a cadaveric study. Spine 2001;26(21):2385-2391

31 Jager ZS, İnceoğlu S, Palmer D, Akpolat YT, Cheng WK. Preventing Instrumentation Failure in Three-Column Spinal Osteotomy: Biomechanical Analysis of Rod Configuration. Spine Deform 2016;4(01):3-9

32 Wang Y, Zhang Y, Zhang X, et al. Posterior-only multilevel modified vertebral column resection for extremely severe Pott's kyphotic deformity. Eur Spine J 2009;18(10):1436-1441

33 Zeng Y, Chen Z, Qi Q et al. Clinical and radiographic evaluation of posterior surgical correction for the treatment of moderate to severe post-tuberculosis kyphosis in 36 cases with a minimum 2-year follow-up. J Neurosurg Spine 2012;16(04):351-358http://www. embase.com/search/results? subaction=viewrecord\&from =export \&id=L364597845\%255Cnhttp://thejns.org/DOI/PDF/10.3171/2011. 12.SPINE11568\%255Cnhttp://dx.doi.org/10.3171/2011.12.SPINE11 568\%255Cnhttp://link.kib.ki.se/?sid=EMBASE\&issn=15475654\&id $=$ doi:10.3171\%252 [Internet]

34 Zeng Y, Chen Z, Guo Z, Qi Q, Li W, Sun C. Complications of correction for focal kyphosis after posterior osteotomy and the corresponding management. J Spinal Disord Tech 2013;26(07): 367-374

35 Zhou T, Li C, Liu B, Tang X, Su Y, Xu Y. Analysis of 17 cases of posterior vertebral column resection in treating thoracolumbar spinal tuberculous angular kyphosis. J Orthop Surg Res 2015;10 (01):64http://josr-online.biomedcentral.com/articles/10.1186/s 13018-015-0195-7 [Internet]

36 Liu C, Lin L, Wang W, Lv G, Deng Y. Long-term outcomes of vertebral column resection for kyphosis in patients with cured spinal tuberculosis: average 8-year follow-up. J Neurosurg Spine 2016;24(05):777-785http://thejns.org/doi/10.3171/2015.8. SPINE15534 [Internet]

37 Atici Y, Balioglu MB, Kargin D, Mert M, Albayrak A, Kaygusuz MA. Analysis of complications following posterior vertebral column resection for the treatment of severe angular kyphosis greater than $100^{\circ}$. Acta Orthop Traumatol Turc 2017;51(03):201-208. Doi: $10.1016 /$ j.aott.2017.02.015 [Internet]

38 Wang H, Guo J, Wang S, et al. Instrumentation Failure After Posterior Vertebral Column Resection in Adult Spinal Deformity. Spine 2017;42(07):471-478http://insights.ovid.com/crossref? an $=00007632-201704010-00010$ [Internet]

39 Young PM, Berquist TH, Bancroft LW, Peterson JJ. Complications of spinal instrumentation. Radiographics 2007;27(03):775-789
40 Ikenaga M, Shikata J, Takemoto M, Tanaka C. Clinical outcomes and complications after pedicle subtraction osteotomy for correction of thoracolumbar kyphosis. J Neurosurg Spine 2007;6 (04):330-336http://www.ncbi.nlm.nih.gov/pubmed/17436922 [Internet]

41 Barrey C, Perrin G, Michel F, Vital JM, Obeid I. Pedicle subtraction osteotomy in the lumbar spine: indications, technical aspects, results and complications. Eur J Orthop Surg Traumatol 2014;24 (Suppl 1):S21-S30

42 Cho KJ, Kim KT, Kim WJ, et al. Pedicle subtraction osteotomy in elderly patients with degenerative sagittal imbalance. Spine 2013;38(24):E1561-E1566

43 Deviren V, Tang JA, Scheer JK, et al. Construct Rigidity after Fatigue Loading in Pedicle Subtraction Osteotomy with or without Adjacent Interbody Structural Cages. Global Spine J 2012;2(04): 213-220

44 La Barbera L, Brayda-Bruno M, Liebsch C, et al. Biomechanical advantages of supplemental accessory and satellite rods with and without interbody cages implantation for the stabilization of pedicle subtraction osteotomy. Eur Spine J 2018;27(09):2357-2366. Doi: 10.1007/s00586-018-5623-z [Internet]

45 Hallager DW, Gehrchen M, Dahl B, et al. Use of Supplemental Short Pre-Contoured Accessory Rods and Cobalt Chrome Alloy Posterior Rods Reduces Primary Rod Strain and Range of Motion Across the Pedicle Subtraction Osteotomy Level: An In Vitro Biomechanical Study. Spine 2016;41(07):E388-E395

46 Lehmer SM, Keppler L, Biscup RS, Enker P, Miller SD, Steffee AD. Posterior transvertebral osteotomy for adult thoracolumbar kyphosis. Spine 1994;19(18):2060-2067

47 Berven SH, Deviren V, Smith JA, Emami A, Hu SS, Bradford DS. Management of fixed sagittal plane deformity: results of the transpedicular wedge resection osteotomy. Spine $2001 ; 26(18)$ : 2036-2043

48 Bianco K, Norton R, Schwab F, et al; International Spine Study Group. Complications and intercenter variability of three-column osteotomies for spinal deformity surgery: a retrospective review of 423 patients. Neurosurg Focus 2014;36(05):E18

49 Quraishi NA, Lewis SJ, Kelleher MO, Sarjeant R, Rampersaud YR, Fehlings MG. Intraoperative multimodality monitoring in adult spinal deformity: analysis of a prospective series of one hundred two cases with independent evaluation. Spine 2009;34(14): 1504-1512

50 Daniel JW, Botelho RV, Milano JB, et al. Intraoperative Neurophysiological Monitoring in Spine Surgery: A Systematic Review and Meta-Analysis. Spine 2018;43(16):1154-1160

51 Modi HN, Suh SW, Hong JY, Yang JH. The effects of spinal cord injury induced by shortening on motor evoked potentials and spinal cord blood flow: an experimental study in Swine. J Bone Joint Surg Am 2011;93(19):1781-1789 